\title{
E-COMMERCE KARYA SENI PADA BORNEO ART ENTHUSIAST
}

\author{
${ }^{1}$ Luluk Nindy Rizky Amanda \\ ${ }^{2}$ Silvia Ratna \\ Fakultas Teknologi Informasi, Universitas Islam Kalimantan \\ Muhammad Arsyad Al Banjari Banjarmasin \\ Email : lulukbjm@gmail.com \\ Fakultas Teknologi Informasi, Universitas Islam Kalimantan \\ Muhammad Arsyad Al Banjari Banjarmasin \\ Email : via.Borneo@gmail.com
}

\begin{abstract}
ABSTRAK
Aplikasi Penjualan merupakan suatu hal yang bukan asing lagi di sebuah industri. Pada Borneo Art Enthusiast, Aplikasi Penjualan ini sangat diperlukan untuk melakukan proses jual beli. Di dalam Penjualan banyak hal yang menjadi kendala diantaranya proses jual beli, pemberian informasi dan promosi. Penanganan data menggunakan sistem manual mengakibatkan sering terjadi kesalahan. Dalam perkembangan industri, masih banyak yang melakukan proses jual beli dengan menggunakan sistem manual yang membutuhkan ketelitian dan proses yang sangat lama. Oleh karena itu, Aplikasi Penjualan ini dapat menyelesaikan masalah.

Tujuan dari penelitian adalah untuk meningkatkan efektifitas dan efisiensi dalam melakukan proses jual beli yang berbasis web sehingga mampu mendukung kinerja Borneo Art Enthusiast. Metode yang digunakan dalam penelitian ini yaitu metode SDLC (Systems Development Life Cycle). Aplikasi ini dikembangkan dengan menggunakan Adobe Dreamweaver CS6, Xampp dan MySQL sebagai database.

E-Commerce Karya Seni Pada Borneo Art Enthusiast menyediakan beberapa fasilitas yang dapat digunakan oleh pengguna, meliputi : input data pengguna, input kategori produk, input produk, input pengiriman, input ongkos kirim, dan laporan penjualan.
\end{abstract}

Kata Kunci: Adobe Dreamweaver CS6, Aplikasi Penjualan Barang, Metode SDLC, MySql, Xampp

\section{PENDAHULUAN}

Perusahaan-perusahaan yang termasuk dalam industri kecil, menengah maupun besar, semakin dipacu untuk menggunakan teknologi yang terus berkembang dan maju untuk tetap survive dan memenangkan persaingan di daerah sampai pada tingkat global. Oleh karena itu, teknologi web di internet memainkan peran yang sangat penting, yaitu memungkinkan organisasi atau perusahaan memasuki pasar dengan cara yang lebih mudah, murah, serta jangkauan yang luas, semuanya akan berada dalam apa yang dinamai ruang maya (Cyberspace).

Salah satu jenis implementasi teknologi informasi dalam hal meningkatkan persaingan bisnis adalah dengan menggunakan electronic commerce (e-commerce). Menurut Laudon \& Laudon (1998), e-commerce adalah suatu proses memjual dan menjual produk-produk secara elektronik oleh konsumen dan dari perusahaan ke perusahaan dengan komputer sebagai perantara transaksi bisnis.

Borneo Art Enthusiast merupakan sebuah komunitas para pembuat karya seni untuk belajar, mempamerkan, sekaligus melayani pemesanan dan penjualan karya seni mereka. Dalam melakukan kegiatannya, Borneo Art Enthusiast yang disingkat menjadi Bartiast masih menggunakan media penyampaian informasi yang sederhana sehingga untuk pemasaran produk dan layanannya masih belum maksimal. Dengan masalah yang dihadapi oleh Bartiast, maka dibutuhkan sebuah sistem informasi berbasis 
web, hal ini sangatlah penting demi mencapai visi misinya karena sebuah sistem informasi dapat menjadi solusi terhadap kendala tersebut. Dalam penelitian ini akan dibuat suatu ECommerce Karya Seni Pada Borneo Art Enthusiastyang diberi judul "E-Commerce Karya Seni Pada Borneo Art Enthusiast".

\section{LANDASAN TEORI}

\section{Pengertian Sistem}

Sistem merupakan jaringan dari elemenelemen yang saling berhubungan, membentuk suatu kesatuan untuk melaksanakan suatu tujuan pokok dari sistem tersebut. Tujuan pokok dari sistem komputer adalah mengolah data untuk menghasilkan informasi. Sistem yang dimaksud disini adalah sistem yang terotomatisasi, yang merupakan bagian dari sistem manusia dan berinteraksi atau dikontrol oleh satu atau lebih komputer sebagai bagian dari sistem yang digunakan (Kadir, 2003).

Suatu sistem memiliki karakteristik atau sifat-sifat tertentu, yaitu (Kadir, 2003):

1. Komponen Sistem (System Component)

Suatu sistem terdiri dari sejumlah komponen yang saling bekerjasama membentuk suatu kesatuan. Komponen-komponen sistem atau elemen sistem dapat berupa suatu kesatuan subsistem atau bagian-bagian dari sistem, perhatikan gambar 2.1 Elemen-elemen Sistem (HM, 1999).

2. Batas Sistem (System Boundary)

Merupakan daerah yang membatasi antara suatu sistem dengan suatu sistem yang lain atau dengan lingkungan luarnya.

3. Lingkungan Luar Sistem (System

Environment)

Lingkungan luar dari suatu sistem adalah batas luar sistem yang mempengaruhi operasi sistem. Lingkungan luar sistem dapat bersifat menguntungkan dan dapat juga bersifat merugikan sistem tersebut.

4. Penghubung Sistem (System Interface)

Merupakan media penghubung antara suatu subsistem dengan subsistem yang lain dan memungkinkan sumber daya yang mengalir dari suatu subsistem ke subsistem lain. Keluaran (output) dari suatu subsistem akan menjadi masukan (input) untuk subsistem yang lainnya dengan melalui penghubung.

5. Masukan Sistem (Input System)
Masukan dapat berupa masukan perawatan (maintenance input) dan masukan sinyal (signal input). Maintenance input adalah energi yang dimasukan supaya sistem tersebut dapat beroperasi. Signal input adalah energi yang diproses untuk subsistem yang lain.

6. Pengolah Sistem (System Output)

Suatu sistem dapat mempunyai suatu bagian pengolah yang akan merubah masukan menjadi keluaran atau sistem itu sendiri sebagai pengolahnya.

7. Sasaran Sistem (System Objectives)

Sistem harus mempunyai sasaran. Sasaran dari sistem sangat menentukan sekali masukan yang dibutuhkan sistem dan keluaran yang akan dihasilkan sistem. Sedangkan suatu sistem dikatakan berhasil apabila mengenai sasaran atau tujuan.

\section{Pengertian Informasi}

Informasi yaitu data yang telah diolah menjadi sebuah bentuk yang berarti bagi penerimanya dan bermanfaat dalam mengambil keputusan saat ini atau mendatang. Informasi dapat mengenai data mentah, data tersusun, kapasitas sebuah saluran komunikasi dan sebagainya. Ada beberapa pandangan mengenai informasi yaitu informasi dapat memperkaya penyajian, mempunyai nilai kejutan, atau mengungkap sesuatu yang penerimaanya tidak tahu atau tidak disangka, informasi dapat mengurangi keraguan dan pilihan. Informasi adalah hasil dari pengolahan data dalam suatu bentuk yang lebih berguna dan lebih berarti bagi penerimanya yang menggambarkan suatu kejadian - kejadian (event) yang nyata (fact) yang digunakan untuk pengambilan keputusan (HM, 1999).

\section{Pengertian Sistem Informasi}

Sistem informasi adalah merupakan suatu sistem yang dibuat oleh manusia yang terdiri dari komponen-komponen dalam organisasi untuk mencapai suatu tujuan yaitu menjadikan informasi (Wahyono, 2004).

Dalam suatu sistem informasi terdapat komponen-komponen, meliputi (Kadir, 2003):

1. Perangkat keras (hardware) : mencakup piranti-piranti fisik seperti komputer dan printer. 
2. Perangkat lunak (software) atau aplikasi : sekumpulan intruksi yang memungkinkan perangkat keras untuk dapat memproses data.

3. Prosedur : sekumpulan aturan yang dipakai untuk mewujudkan pemrosesan data dan pembangkitan keluaran yang dikehendaki.

4. Orang : semua pihak yang bertanggung jawab dalam pengembangan sistem informasi, pemrosesan, dan penggunaan keluaran sistem informasi.

5. Basis data (database) : sekumpulan tabel, hubungan, dan lain-lain yang berkaitan dengan penyimpanan data.

6. Jaringan komputer dan komunikasi data : sistem penghubung yang memungkinkan sumber (resource) dipakai secara bersama atau diakses oleh sejumlah pemakai.

\section{Basis Data (Database)}

Basis data adalah kumpulan data yang saling berhubungan dari suatu enterprise (perusahaan, instansi pemerintah atau swasta). Penerapan database dalam sistem informasi disebut dengan database system.

Basis data merupakan kumpulan dari informasi yang berhubungan dengan subjek atau fungsi tertentu, seperti menangani pemasukan data konsumen/user baru. Prinsip utama basis data adalah pengaturan data. Basis data menggunakan suatu Sistem Manajemen Database (DBMS) yang dapat menempatkan database dalam suatu file, dan mengorganisasikannya menjadi tabel-tabel dan mengkoordinir data tersebut menjadi laporan dengan berbagai fasilitas. Model relational merupakan standar untuk rancangan database, dimana database disimpan dan ditampilkan sebagai suatu koleksi dari tabel-tabel.

Elemen basis data pada sistem informasi berfungsi sebagai media untuk penyimpanan data dan informasi yang dimiliki oleh sistem informasi tersebut.

\section{Pengertian E-Commerce}

E-commerce adalah kegiatan-kegiatan bisnis yang menyagkut konsumen (consumers), manufaktur (manufaktures), service providers dan pedagang perantara (intermediaries), dengan menggunakan jaringan-jaringan komputer (computer networks) yaitu internet

(Berkatullah \& Prasetyo, 2005).

Ada tiga tipe utama dari E-Commerce antara lain:

1. B2C (Business-to-Customer)

Di dalam transaksi $\mathrm{B} 2 \mathrm{C}$, transaksi online dibuat antara bisnis dengan konsumen. Transaksi ini meliputi transaksi penjualan dengan pemjual-pemjual individu.

2. $\mathrm{B} 2 \mathrm{~B}$ (Business-to-Business)

Di dalam B2B, transaksi online dilakukan antara bisnis dan bisnis lain. Partisipasinya meliputi bisnis atau organisasi lainnya.

3. B2E (Business-to-Employee)

Di dalam B2E, transaksi online dilakukan antara bisnis dan pegawai atau karyawan. Transaksi yang ada hanya berupa informasi dan servis untuk kepentingan bisnis perusahaan.

Ada tiga keuntungan atau manfaat dalam melakukan perdagangan elektronik, yaitu (Nugroho, 2004):

1. Keuntungan bagi perusahaanMemperpendek jarak, memperluas pasar, dan perluasan jaringan mitra bisnis.

2. Keuntungan bagi Konsumen Efektif, aman secara fisik, dan fleksibel.

3. Keuntungan bagi Masyarakat Umum Membuka peluang kerja baru, mengurangi polusi dan pencemaran lingkungan, dan menigkatkan kualitas sumber daya manusia.

\section{Pengertian Internet}

Internet adalah kumpulan atau jaringan dari komputer yang ada diseluruh dunia. Internet (kependekan dari interconnectionnetworking) secara harfiah ialah sistem global dari seluruh jaringan komputer yang saling terhubung menggunakan standar Internet Protocol Suite (TCP/IP) untuk melayani miliaran pengguna di seluruh dunia.

\section{Pengertian WWW (World Wide Web)}

World Wide Web (WWW) dapat juga disebut web adalah sistem informasi dan komunikasi Hypertext yang sangat popular digunakan pada jaringan komputer internet 
yang mampu menampilkan informasi secara grafis dan interaktif (Purbo, 2006).

WWW atau sering disingkat web, yang berisi halama-halaman yang dapat menampilkan teks, gambar, grafik, suara, animasi, serta elemen-elemen multimedia lainnya dan elemen-elemen yang ditampilkan bersifat interaktif.

\section{Pengertian PHP}

PHP adalah sebuah bahasa pemrograman yang berbentuk scripting, sistem kerja dari program ini adalah sebagai interpreter bukan sebagai compiler (Nugroho, 2004).

PHP (personal home page tools) merupakan kependekatan dari kata Hypertext preprocessor. PHP tergolong sebagai perangkat lunak open source yang diatur dalam aturan general purpose lincences (GPL) dan tergolong sebagai bahasa pemograman yang berbasis server (server side scripting). Pemograman PHP sangat cocok dikembangkan dalam lingkungan web, karena PHP bisa diletakan pada script HTML atau sebaliknya.

\section{Pengertian MySQL}

MySQL merupakan perangkat lunak yang tergolong sebagai DBMS (Database Management System), yang sifatnya open source. Open source menyatakan bahwa perangkat lunak ini dilengkapi dengan source code (kode yang dipakai untuk membuat MySQL), selain itu kode tersebut dapat langsung dijalankan dalam system operasi, dan dapat diperoleh dengan cara mendownload di internet secara gratis.

\section{Pengertian Xampp}

Xampp merupakan perangkat lunak yang dapat di download secara gratis dan di dalam perangkat lunak ini, berisi kumpulankumpulan beberapa perangkat lunak yang dibutuhkan antara lain PHP, Apache, MySQL dan PHPMyAdmin userikan kemudahan dalam pengoperasiannya dan hamper semua web hosting menyediakan PHPMyAdmin untuk para penyewa virtual host (Suprianto, 2007).

Fungsi XAMPP sendiri adalah sebagai serveryang berdiri sendiri (localhost), yang terdiri beberapa program antara lain : Apache HTTP Server, MySQL database, dan penerjemah bahasa yang ditulis dengan bahasa pemrograman PHP dan Perl.

Server HTTP Apache atau Server Web/WWW Apache adalah server web yang dapat dijalankan di banyak sistem operasi seperti (Unix, BSD, Linux, Microsoft Windows dan Novell Netware serta platform lainnya) yang berguna untuk melayani dan memfungsikan situs web. Protokol yang digunakan untuk melayani fasilitasweb/www ini menggunakan HTTP.

\section{Pengertian Adobe Dreamweaver CS6}

Adobe Dreamweaver CS6 adalah software terkemuka untuk membangun dan mengedit web dengan menyediakan kemampuan visual dan tingkat kode yang dapat digunakan untuk membuat website berbasis standar dan desain untuk desktop, mobile, smartphone, tablet dan perangkat lainnya (Andi \& MadCom, 2011).

\section{METODE PENELITIAN}

\section{Analisis Sistem Yang Berjalan}

Proses sistem yang telah berjalan di dalam proses pemesanan dan penjualan produk karya seni, ketika admin mendapat permintaan dari konsumen berupa pemesanan suatu produk melalui media sosial, admin akan merekomendasikan beberapa seniman dengan bidang yang sesuai dengan jenis karya seni yang diminta. Kemudian konsumen akan menghubungi seniman tersebut melalui media sosial untuk melalukan proses jual beli produk. Di dalam proses tersebut, seniman akan userikan daftar harga produk beserta referensi produk dalam bentuk foto, sehingga konsumen dapat mempertimbangkan untuk melakukan pemesanan atau tidak. Apabila pemesanan berhasil dilakukan, seniman dan konsumen akan melakukan transaksi penjualan secara langsung.

\section{Analisis Kebutuhan Sistem}

SDLC (System Development Life Cycle) merupakan sebuah siklus hidup pengembangan perangkat lunak yang terdiri dari beberapa 
tahapantahapan yang sangat penting dalam keberadaan perangkat lunak yang dilihat dari segi pengembangnya.

$$
\text { Tahapan-tahapan SDLC (System }
$$
Development Life Cycle) dalam Sistem Informasi Penjualan Karya Seni Berbasis Web Pada Borneo Art Enthusiast, sebagai berikut :

1. Perencanaan

Perencanaan adalah feasibility, wawancara, observasi dan kuesioner. Dalam tahapan ini, dilakukan wawancara dan observasi. Wawancara dilakukan kepada Ketua Borneo Art Enthusiast. Sedangkan observasi dilakukan pengamatan sistem berjalan yang dilakukan di basecamp Bartiast. Hasil Observasi yang didapat adalah data-data produk karya seni.

\section{Analisa}

Dalam tahap ini, penulis melakukan 2 (dua) analisa, yaitu:

a) Analisa Teknologi: Menganalisa teknologi penyimpanan data menggunakan MySQL dan software pendesain aplikasi berbasis web, seperti Adobe Dreamweaver CS6.

b) Analisis Informasi: Mengenai analisa informasi, penulis akan melakukan analisa terhadap data yang akan digunakan pada pengembangbangan Sistem Informasi Penjualan Karya Seni Berbasis Web Pada Borneo Art Enthusiast.

3. Desain

Desain terbagi menjadi 3 (tiga), yaitu informasi, database dan aplikasi.

a) Desain Informasi

Dalam tahap ini, dibuat model informasi yang akan menjadi input/output dari aplikasi tersebut.

b) Desain Basis Data

Dalam tahap ini, penulis mendesain basis data dengan membuat ERD dan DFD yang nantinya akan digunakan dalam pengembangan Sistem Informasi Penjualan Karya Seni Berbasis Web Pada Borneo Art Enthusiast.

c) Desain Aplikasi

Dalam tahap ini, penulis mendesain antar muka aplikasi sesuai dengan kebutuhan mulai dari menu, warna dan lay out.

4. Implementasi Sistem

Penganalisaan program dan instalasi merupakan tahap program yang telah dianalisis dan program yang akan digunakan adalah Adobe Dreamweaver CS6 dan MySQL sebagai aplikasi penyimpanan basis data.

5. Pengujian Sistem

Tahap pengujian yang dilakukan ada 2 (dua), yaitu:

a) Desain Review

Dalam tahap ini, penulis menguji semua sistem yang telah diterapkan pada Borneo Art Enthusiast.

b) Pemilihan Sumber Daya Hardware dan Software

Dalam tahap ini, hardware dan software yang digunakan sesuai dengan kebutuhan sistem.

6. Pemeliharaan Sistem

Dalam tahap ini, penulis mengulas bagaimana cara pemeliharaan pengembangan E-Commerce Karya Seni Pada Borneo Art Enthusiastsebagai berikut:

a) Menangani Error System

Dalam penelitian ini, tersedia tahapan yang akan digunakan sebagai cara apabila sistem terjadi masalah (error).

b) System Back Up Database

Dalam tahapan ini, apabila data hilang atau terjadi sesuatu pada data tersebut, data masih bias tersimpan dengan aman.

\section{Rancangan Model Sistem \\ Contex Diagram}

Tahap pertama dalam perancangan model sistem dengan membuat context diagram yaitu dimana sistem dapat digambarkan dengan lingkaran tunggal yang mewakili keseluruhan sistem informasi.

Berikut ini context diagram yang digunakan dalam Sistem Informasi Penjualan Karya Seni Berbasis Web Pada Borneo Art Enthusiast: 


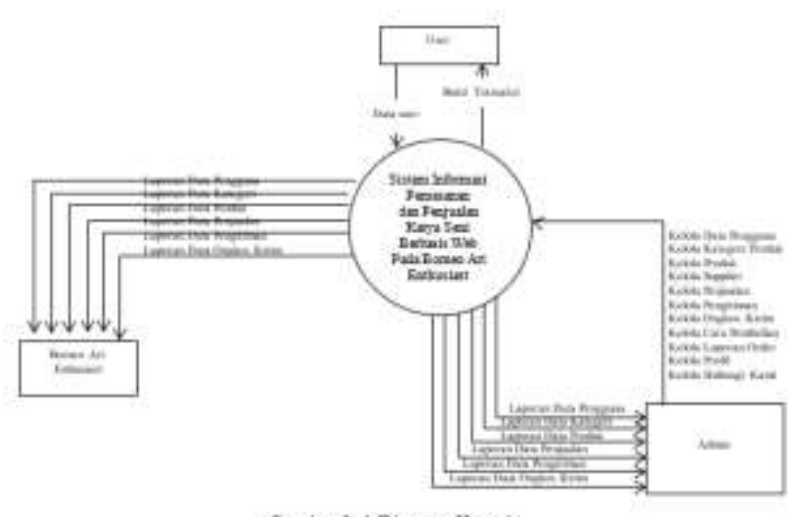

Gambae 3. 1 Diagram Koateks

Dilihat dari gambar 3.1 Diagram Konteks, maka pengguna/user yang ingin membeli produk melalui E-Commerce Karya Seni Pada Borneo Art Enthusiastdapat memilih produk, mengisi quantity, data pembeli dan mendapatkan bukti proses transaksi. Sedangkan admin bertugas mengelola data sistem serta memperoleh laporan dari masukan data. Sistem Informasi Penjualan Karya Seni akan memberikan sebuah laporan tentang penjualan karya seni untuk Borneo Art Enthusiast (Bartiast).

\section{DFD (Data Flow Diagram)}

DFD merupakan suatu model logika data atau proses yang dibuat untuk menggambarkan dari mana asal data dan kemana tujuan data yang keluar dari sistem.

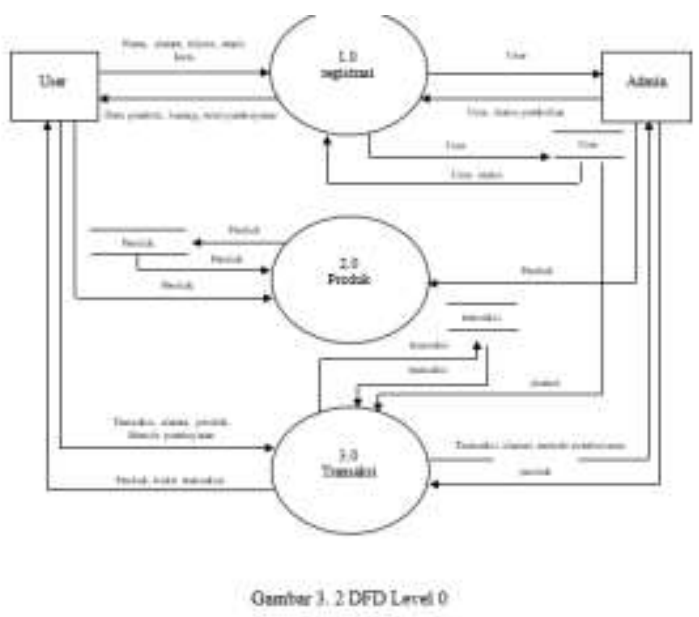

Pada gambar 4.6 ini, terdapat entity yaitu user dan admin yang menggambarkan proses dengan lima proses yang ada yaitu proses 1.0 yakni proses mengolah tanya jawab, proses 2.0 yakni proses mengolah user, proses 3.0 yakni proses mengolah transaksi, proses 4.0 yakni proses mengolah admin.

\section{Tampilan Aplikasi}

1. Form Login

Form login adalah pintu masuk ke dalam sistem yang berfungsi untuk menjaga keamanan data agar tidak semua orang dapat masuk dan mengakses kecuali orang-orang yang telah terdaftar. Berikut tampilan form login:

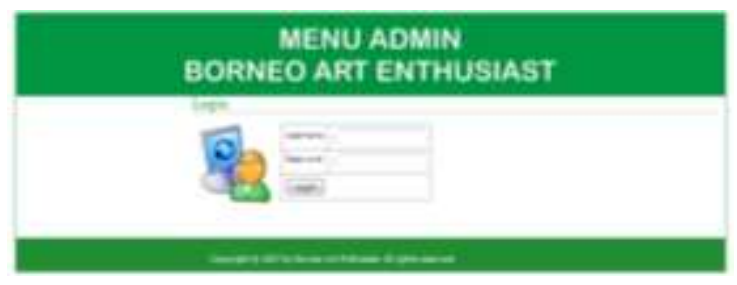

\section{Form Tambah Pengguna}

Form tambah pengguna adalah form input data pengguna. Berikut tampilan form tambah pengguna:

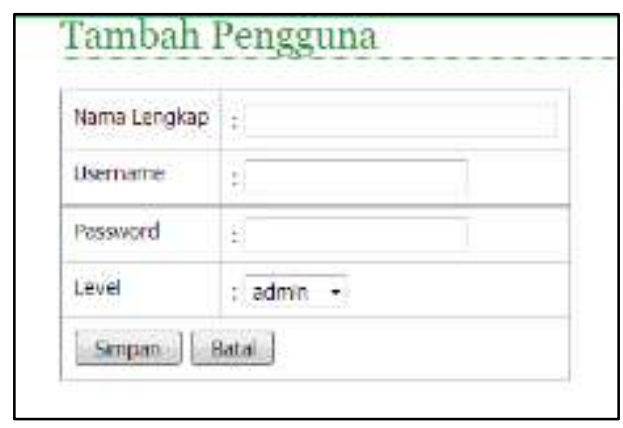

3. Form Tambah Produk

Form tambah produk adalah form input data produk. Berikut tampilan form tambah pengguna:

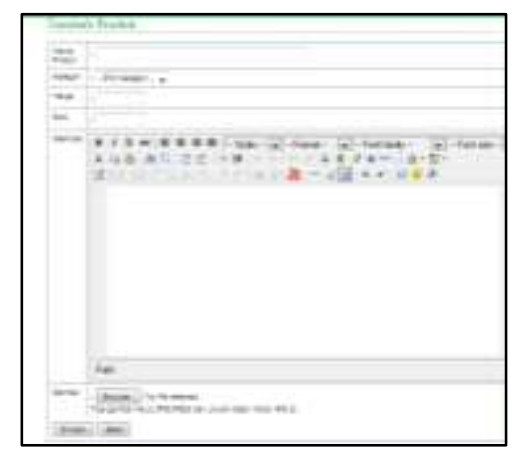

4. Form Data Pembeli 
Form data pembeli adalah form input data pembeli. Berikut tampilan form data pembeli:

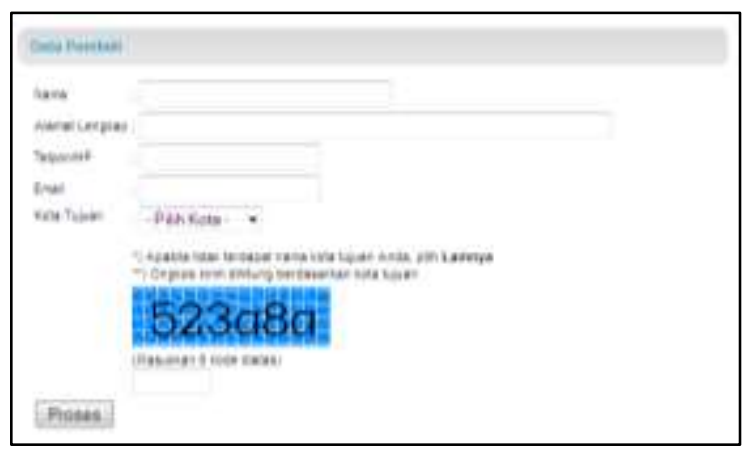

5. Form Tambah Pengiriman

Form tambah pengiriman adalah form input data pengiriman barang. Berikut tampilan form tambah pengiriman:

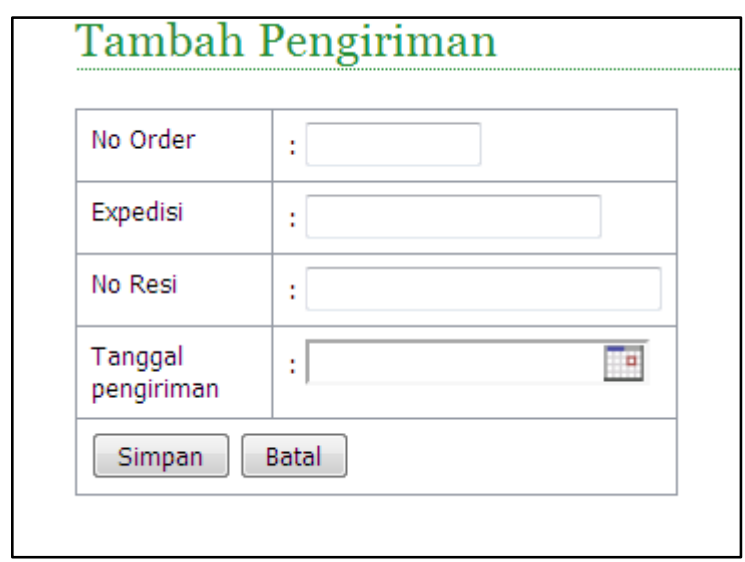

6. Laporan Data Pengguna

Laporan data pengguna menampilkan informasi data pengguna yang sudah diinput ke dalam sistem yang nantinya akan dicetak. Berikut tampilan laporan data data pengguna:

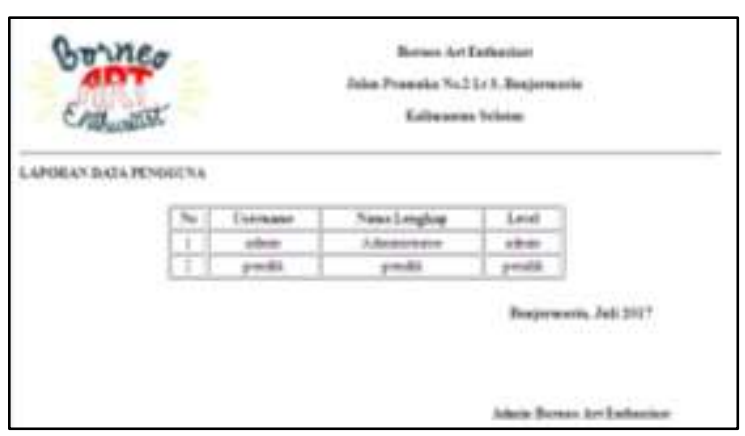

7. Laporan Data Produk

Laporan data produk menampilkan informasi data produk yang sudah diinput ke dalam sistem yang nantinya akan dicetak. Berikut tampilan laporan data produk:

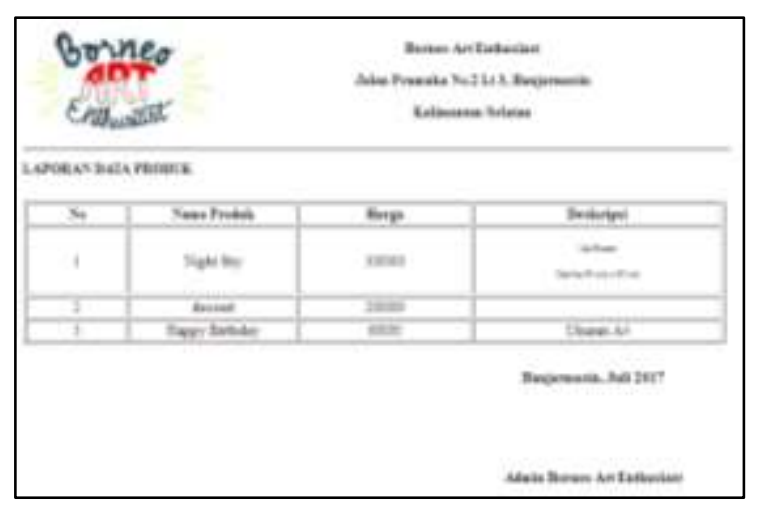

8. Bukti Transaksi Pembelian

Bukti transaksi pembelian adalah data hasil input transaksi produk yang dibeli beserta data pembeli. Berikut tampilan bukti transaksi pembelian:

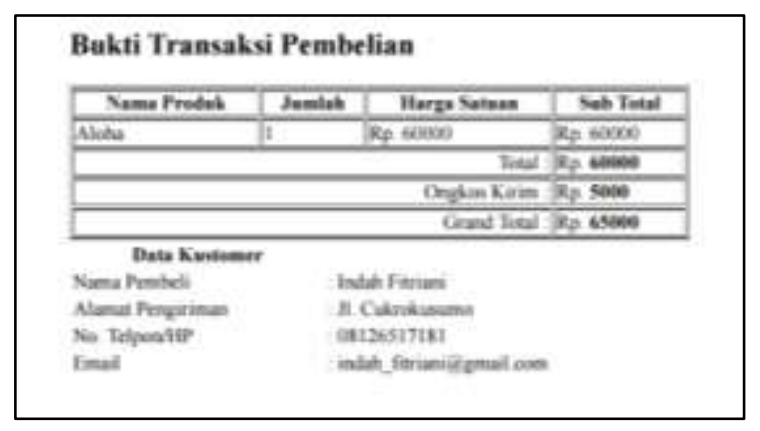

9. Laporan Data Penjualan

Laporan data penjualan menampilkan informasi data penjualan yang sudah diinput ke dalam sistem yang nantinya akan dicetak. Berikut tampilan laporan data penjualan:

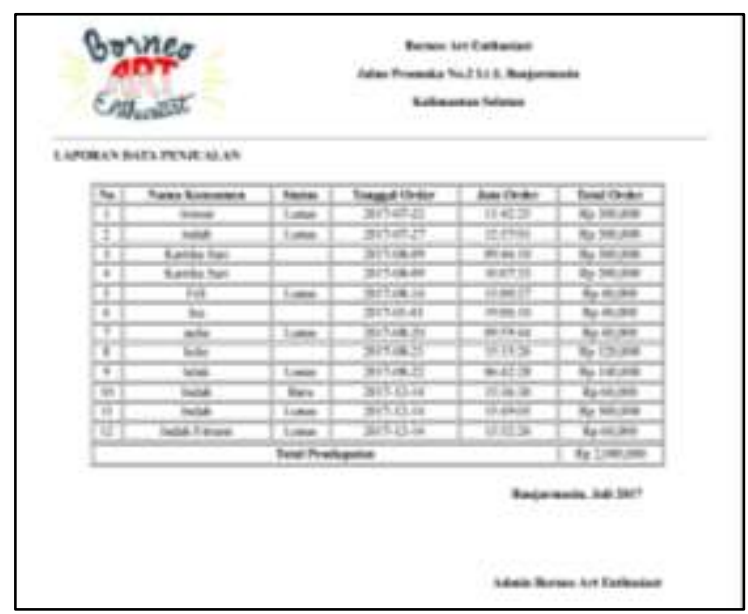




\section{KESIMPULAN}

Berdasarkan pembahasan di atas, maka dapat ditarik kesimpulan tentang E-Commerce Karya Seni Pada Borneo Art Enthusiast antara lain:

1. Sistem informasi ini dapat mempermudah admin dalam memproses pemesanan dan penjualan karya seni pada Borneo Art Enthusiast.

2. Sistem informasi ini dapat mempermudah dan mempercepat dalam mengelola data pemesanan dan penjualan karya seni, menyimpan data kostumer secara aman karena terintegrasi dalam satu database.

3. Sistem Informasi Pemesanan dan Penjualan Karya Seni Berbasis Web mempermudah penyebaran informasi dan promosi sehingga dapat meningkatkan produksi Borneo Art Enthusiast.

4. Sistem informasi ini dapat mempermudah dalam pembuatan laporan data hasil pemesanan dan penjualan untuk dilaporkan kepada pemilik Borneo Art Enthusiast.

\section{DAFTAR PUSTAKA}

Andi \& MadCom. (2011). Aplikasi Web Database dengan Dreamweaver dan PHP-MySQL. Yogyakarta: Andi Offset.

Apriyanto \& N. Candra. (2011). Sistem Informasi Penjualan Arloji Berbasis Web pada CV. Sinar Terang Semarang. Yogyakarta: Universitas Pembangunan Nasional Veteran.

Berkatullah \& Prasetyo. (2005). Bisnis Ecommerce: Studi Sistem Keamanan dan Hukum di Indonesia. Yogyakarta: Pustaka Pelajar.
Ginting, E. (2013). Sistem Informasi Penjualan Berbasis Web (e-commerce) menggunakan Joomla pada Mutiara Fashion. Bandung: Universitas Widyatama.

HM, J. (1999). Analisis dan Desain Informasi: Pendekatan Terstruktur Teori dan Praktek Aplikasi Bisnis. Yogyakarta: Andi Offset.

Iyas. (2011). Implementasi Sistem Penjualan Online Berbasis E-commerce. Jakarta: Universitas Islam Negeri Syarif Hidayatullah.

Kadir, A. (2003). Implementasi Sistem Penjualan Online Berbasis Ecommerce. Yogyakarta: Andi Offset.

Nugroho, A. (2004). E-Commerce Memahami Perdagangan Modern di Dunia Maya. Bandung: Informatika Bandung.

Purbo, W. (2006). Buku Pegangan Internet Wireless dan Hotspot. Jakarta: Elex Media Komputindo.

Supriyanto, A. (2008). Web dengan HTML dan $X M L$. Yogyakarta : Graha Ilmu.

Wahyono, T. (2004). Sistem Informasi (Konsep Dasar, Analisis, Desain dan Implementasi). Yogyakarta: Graha Ilmu. 